ARTICLE

\title{
Group Company Liability
}

\section{Martin Petrin ${ }^{1} \cdot$ Barnali Choudhury ${ }^{1}$}

Published online: 23 October 2018

(c) The Author(s) 2018

\begin{abstract}
According to a universal bedrock principle of corporate law, corporations have separate legal personality and limited liability. These principles apply equally to corporate groups. Accordingly, a parent company is normally not liable for legal infractions and unpaid debts of its subsidiaries. In relation to torts and other misconduct committed by corporations, however, the bedrock principles of corporate law are increasingly subject to criticism, in particular where such claims cannot be brought by tort victims due to undercapitalization of subsidiaries, among other problems. While the doctrine of veil piercing may allow for relief in certain scenarios, this practice has fallen out of favour with many courts and the legal requirements for doing so have become increasingly strict. Thus, courts have developed new approaches to holding parent companies liable such as holding the parent directly liable. In view of these significant shifts, this article examines the law and policy considerations governing parent company and-more broadly-group liability. It argues that reform is necessary, which may be found in a model that involves combinations of voting equity ownership-based enterprise liability concepts with modified vicarious liability for corporations.
\end{abstract}

Keywords Group company $\cdot$ Liability $\cdot$ Corporate law $\cdot$ Tort law $\cdot$ Multinational corporations

Barnali Choudhury

b.choudhury@ucl.ac.uk

Martin Petrin

m.petrin@ucl.ac.uk

1 University College London, Faculty of Laws, London, UK 


\section{Introduction}

According to a universal bedrock principle of corporate law, corporations have separate legal personality - which separates them from their shareholders, directors, officers, and other individuals - as well as limited liability for shareholders. ${ }^{1}$ These principles, which together form the corporate shield, apply equally to corporate groups. Accordingly, a parent company is normally not liable for legal infractions and unpaid debts at the level of subsidiaries of which it is a direct or indirect shareholder. Particularly in relation to torts and other misconduct committed or facilitated by large and multinational corporations, the principles encompassing the corporate shield have increasingly been subject to criticism. ${ }^{2}$ The limits imposed by the corporate shield do not normally give rise to issues in instances where third party tort victims can pursue claims against the subsidiary and the subsidiary has sufficient assets. However, problems arise when such claims are not possible or futile because of a lack of assets of an entity, an issue which is predicted to become more prevalent in the future. ${ }^{3}$

Nevertheless, there are exceptions to the default principles of corporate separateness, which if applicable also allow courts to hold parent companies liable for misconduct at the subsidiary level. The best known of these exceptions is referred to as veil piercing. In these instances, a court may look for specific requirements that allow it to disregard the separation between a company and its shareholder(s), which can extend to a subsidiary and its parent company. However, veil piercing has fallen out of favour with many courts and commentators, and the legal requirements for doing so have become increasingly strict. Thus, courts have developed new approaches to holding parent companies liable. The most significant recent development is the recognition of duties of a parent company relating to its supervision and management of subsidiaries, which, if there is a breach, may lead to the parent's own direct liability. Additionally, there are efforts underway that could result in an internationally mandated liability regime for parent companies, which would hold them directly responsible for subsidiaries' human rights violations.

In view of these significant shifts, this article examines the law and policy considerations governing parent company and-more broadly_-group liability. The article begins with a brief look at the phenomenon of corporate groups and the role of limited liability in this context. Next, it examines tools that currently can be used to circumvent limited liability in groups, providing an overview of traditional veil piercing and its demise, followed by a discussion and critique of the emerging doctrine of direct liability based on the parent's own duty of care. It then moves to examine the fundamental question whether there is a case for expanding liability within corporate groups. The discussion then shifts to various reform proposals for parent

\footnotetext{
1 See, for example, Companies Act (2006), Sect. 3. Although the separate legal personality and limited liability features often coincide, they are at least in theory conceptually distinct and independent of each other.

2 See Sect. 5 below on efforts to reform the law on parent company and group liability.

3 Witting (2018), p 7.
} 
company liability and their assessment. In the final section, the article outlines a preferred approach, which combines voting equity ownership-based enterprise liability concepts with modified vicarious liability for corporations that allows for liability within more loosely formed corporate networks, specifically including those based on solely contractual relationships.

\section{The Group Company and Limited Liability}

Group companies ('corporate groups') are business enterprises or firms that order their operations using a structure involving parent companies ('holding companies') and subsidiaries. In the UK and the US, a common group structure involves a parent company that owns shares, wholly or partially, in a group of subsidiaries, which may themselves hold shares in or be intermediary parent/holding companies for other subsidiaries. ${ }^{4}$ A core conception of the group company is thus one that is comprised of several companies related hierarchically through controlling shareholdings, which can manifest itself in the form of majority as well as indirect and minority shareholdings. In a wider conception, group companies can also refer to structures without hierarchical shareholdings-such as where common control stems from family ownership or in instances of significant but non-controlling cross-holdings or circular holdings in conjunctions with common management ${ }^{5}$ or corporate networks. Although the distinction between groups and networks is not always clear and can overlap, networks are companies whose relationship is not characterized by the potential for equity-based control but rather through 'detailed cooperation agreements, and/or repeated transactions' ${ }^{6}$ Typical examples are businesses that cooperate or support each other's efforts in product development, manufacturing, and distribution. $^{7}$

When subsidiaries operate in jurisdictions other than where the (ultimate) parent company is headquartered, a group may be described as a multinational corporation. Group companies that transcend borders are a common choice for structuring business operations. Yet, despite this widespread occurrence in practice, the legal status of corporate groups remains often somewhat obscure. The UK Companies Act 2006, for example, contains only sparse references to groups, among a few other instances most notably in relation to their accounting, reporting, and auditing obligations. ${ }^{8}$ Additionally, the UK Corporate Governance Code does not explicitly mention corporate groups anymore, apart from a reference to the Financial Conduct Authority's Disclosure and Transparency Rules on reporting requirements. ${ }^{9}$

\footnotetext{
${ }^{4}$ Muchlinski (2007), p 56. The subsidiaries themselves can also be referred to as group companies. We will however use this term for the group as a whole.

5 Witting (2018) pp 3-4.

6 Ibid., p 5.

7 See ibid., pp 39-47. A classic work on this topic is Teubner (2011).

8 See Parts 15 and 16 as well as sections 208, 611, 682, 834, 1161-1162 and 1164-1165 of the Companies Act; Davies et al. (2012), pp 247-249 and chapter 21.

9 See e.g., DTR 5.1.4B, Disclosure Guidance and Transparency Rules sourcebook (Feb. 2018).
} 
The appeal of using group structures is myriad. Subsidiaries can be used to limit the liability of the parent corporation or other entities in the group, to facilitate the obtaining of financing, to establish domestic corporate residence, to avoid complications associated with the purchase of assets, and as a vehicle to avoid tax. The use of subsidiaries may also facilitate international trade and enable large firms the flexibility to enter into corporate ventures with new combinations of investors. ${ }^{10}$ Despite the variety of advantages that group structures can entail, it is likely that the ability to asset partition-and therefore facilitate judgment-proofing and limiting the group's liability - is the largest benefit for businesses. ${ }^{11}$ While legislatures introduced limited liability in Anglo-American companies without consideration of whether or not it should also apply to corporate shareholders, ${ }^{12}$ when the practical issue came up in the courts it was firmly accepted to extend to parent companies as well. However, group companies' ability to maintain asset partitioning is not absolute. The following section will examine two exceptions.

\section{Circumventing Limited Liability}

Since limited liability for corporate groups can lead to undesirable effects for claimants that were exposed to torts by subsidiaries, numerous efforts have been made to circumvent limited liability for these entities in particular instances and gain access to the assets of a parent company or even a group company's combined assets. Individuals that have found themselves as claimants against these companies have turned to veil piercing as a method of seeking redress. More recently, the emerging tool of choice in these cases are claims based on a parent company's own, direct liability.

\subsection{The Traditional Approach: Veil Piercing}

The House of Lords' 1897 decision in Salomon v. A. Salomon \& Co. ${ }^{13}$ famously upheld statutory provisions stipulating a company's separate legal personality and limited liability, even as applied to a one-man company. Following this landmark case, which also legitimised groups of connected yet legally separate companies, ${ }^{14}$ courts tended to be reluctant to disregard these principles. Nevertheless, especially from the 1960s onwards, a number of cases later reflected a greater willingness on the part of courts to impose liability on shareholders behind a company by 'piercing' or lifting the corporate veil. ${ }^{15}$ In doing so, courts relied on various legal theories, including that a company was only a device or façade to avoid individual obligations; that a company was another, controlling entity's agent; that a group of

\footnotetext{
10 See, for example, Ramsay (1999), pp 338-339; Orts (2013), p 37; Witting (2018), pp 47-48.

11 On judgment-proofing strategies, see LoPucki (1996).

12 Blumberg (1986), p 610; Talbot (2013), pp 22-29; Muchlinski (2010), pp 916-918.

13 [1897] AC 22 (HL) (per Lord Halsbury L.C.).

14 Hannigan (2016), p 43.

15 For the difference between veil lifting and veil piercing see ibid., pp 53-57.
} 
companies formed a single economic unit; or that piercing was necessary to uphold justice. $^{16}$

In the UK, however, the tendency to allow piercing in line with the traditional principles came to a halt with the 1989 decision in Adams v. Cape Industries plc. ${ }^{17}$ The Court acknowledged that there were three main instances in which piercing may be justified. First, when a parent's responsibility for a subsidiary may be construed based on specific circumstances, particularly where a statute or contract allows for a broad interpretation to references to members of a group of companies. Second, in cases indicating that a company is a mere façade to conceal true facts and avoid legal obligations. Third, where a subsidiary acts as its parent company's agent. ${ }^{18}$

The reluctance to pierce the veil was further reflected in cases after Adams, most notably in the recent Prest $v$. Petrodel Resources Ltd. ${ }^{19}$ In that decision, the Supreme Court held that veil piercing 'applies when a person is under an existing legal obligation or liability or subject to an existing legal restriction which he deliberately evades or whose enforcement he deliberately frustrates by interposing a company under his control'. ${ }^{20}$ The reference to existing legal obligations would, by itself, apparently exclude most tortious conduct. ${ }^{21}$ Further, it currently appears that the result of Prest is that there is one definite ground of veil-piercing. The other grounds have not been done away with, but courts will need to re-consider them one by one in future cases. Finally, it is worth noting that Lord Sumption in Prest also opined that piercing should only apply in the absence of other possible remedies. Overall, thus, the decision once more confirmed the restrictive approach to piercing under English law, with veil piercing today remaining an exceptional event.

\subsection{The Emerging Approach: Direct Parent Liability}

After Adams greatly narrowed the possibilities for a successful veil piercing claim, post-Adams, the focus shifted towards new avenues for holding parent companies liable. In order to bypass the difficulties associated with veil piercing, parties injured by conduct emanating from subsidiaries began to initiate claims against their parent companies on the basis that the parent company itself owed the claimants a direct duty of care and had been in breach thereof.

For instance, a decade after Adams, the UK courts began to recognize the possibility of parent company liability. Cases were brought in the UK courts by employees injured by subsidiaries outside of the UK and the courts demonstrated a willingness to recognize parent company liability. ${ }^{22}$ However, often for procedural reasons, no ruling on the issue was made.

\footnotetext{
${ }_{16}$ For a discussion of relevant case law, see Dignam and Lowry (2014), pp 34-42.

17 [1990] Ch 433.

18 Ibid., pp 530-549.

19 [2013] 3 WLR 1. See also VTB Capital Plc v. Nutritek International Corp [2012] EWCA Civ 808.

20 [2013] 3 WLR 1, 20.

${ }^{21}$ Cf., however, Lo (2017) arguing for a broad interpretation of 'obligations' that includes future tort liabilities.

${ }^{22}$ See, e.g., Connelly v. RTZ Corp plc [1999] CLC 533; Lubbe v. Cape plc [2000] 1 WLR 1545; Newton-Sealey v. ArmorGroup Services Ltd. [2008] EWHC 233 (QB).
} 
In 2012, this changed with the first decision to establish parent company liability, Chandler v. Cape. ${ }^{23}$ An employee of a subsidiary of Cape plc suffered injuries due to exposure to asbestos and, as the subsidiary had been dissolved in the meantime, brought claims against the parent company. The Court of Appeal accepted a broad view of the concept of 'assumption of responsibility' and validated its use as a tool for tort victims that were injured by activities of a subsidiary and seek to hold the parent company liable. In doing so, the Court also developed a novel approach for assessing parent company duties relating to the health and safety of subsidiary employees.

Under Chandler's approach, the first inquiry is into the level of control that a parent exercises over a subsidiary. If there is sufficient control, ${ }^{24}$ the parent company may be found to have assumed responsibility towards subsidiary employees and incur liability. Although the Court of Appeal did not specify what exactly would be necessary to trigger such liability, it provided a four-part test that, if all parts can be answered in the positive, was said to be one of the situations leading to parent company liability towards employees of its subsidiaries. The factors formulated by the Court are that (1) the businesses of the parent and subsidiary need to be in a relevant respect the same; (2) the parent has, or ought to have, superior knowledge on some relevant aspect of health and safety in the particular industry; (3) the subsidiary's system of work is unsafe as the parent company knew, or ought to have known; and (4) the parent knew or ought to have foreseen that the subsidiary or its employees would rely on its using that superior knowledge for the employees' protection. ${ }^{25}$

The Court of Appeal faced a variation of Chandler's factual scenario in Thompson v. The Renwick Group plc. ${ }^{26}$ The question for the Court to decide here was, first, "whether a parent can be held to have assumed a duty of care to employees of its subsidiary in health and safety matters by virtue of that parent company having appointed an individual as director of its subsidiary company with responsibility for health and safety matters'. ${ }^{27}$ The Court decided this question in the negative as the director was not acting on behalf of the parent but rather exercised his duties towards the subsidiary. Second, the Court also decided that apart from this specific question the totality of evidence did not justify the imposition of a duty of care on the parent company to protect the subsidiary company's employees from the risk of injury arising out of exposure to asbestos at work.

Finding however that the defendant parent company's role was limited to holding shares in the subsidiary, the Court held that there was no basis upon which it could infer that the parent was in a position of superior knowledge, which would have enabled it to protect subsidiary employees and warranted further examination of the exact circumstances of the injuries and the parent's role. Nevertheless, while Thompson made it clear that parent companies that limited their role to pure holding

\footnotetext{
23 [2012] 1 WLR 3111.

24 Ibid., p 3123.

25 Ibid., p 3131.

26 [2015] 2 BCC 855.

27 Ibid., p 860.
} 
companies-holding subsidiary shares without having their own business activities-are normally safe from liability towards group company employees, this case also reaffirmed the Court of Appeal's commitment to Chandler and the theory of liability developed therein.

Most recently, the Court of Appeal has been tasked with deciding three further cases with factual scenarios similar to Chandler. In Lungowe v. Vedanta Resources ${ }^{28}$ the plaintiffs allege that they had been harmed by pollution and environmental damage caused by the parent's subsidiary in Zambia. The Court of Appeal agreed with the High Court that the English courts have jurisdiction over the matter despite the harm being caused in Zambia. It also offered some tentative holdings on the parameters for establishing parent company liability for the acts of its subsidiary. The Court noted that a parent may owe a duty of care to the employee of a subsidiary, or a party directly affected by the operations of that subsidiary, in certain circumstances. Those circumstances may arise where the parent has taken direct responsibility for devising a material health and safety policy the adequacy of which is the subject of the claim, or, it controls the operations which give rise to the claim. Indeed, the duty may arise because the parent is well placed, due to its knowledge and expertise to protect the employees of the subsidiary. The Court also found that the factors detailed in Chandler and Renwick are relevant.

Two further cases, Okpabi $^{29}$ and Unilever, ${ }^{30}$ which again involve claims by employees and third parties who have been harmed in foreign jurisdictions by the parent's subsidiary, have not been as well received by the courts. In both cases, the High Court dismissed the action against the parent company based mainly on evidentiary reasons, a conclusion that was confirmed by the Court of Appeal in Okpabi. ${ }^{31}$ Unilever still remains on appeal.

\subsection{The Limits of Direct Parent Liability}

Direct (tortious) liability of parent companies in scenarios as outlined above should in principle be approached the same way as tort claims against any company, whether or not they are part of a group company. According to the currently applicable mechanisms for holding companies liable, responsibility can be incurred through vicarious liability for individuals or direct liability. Nevertheless, claims against parent companies, when they stem from occurrences involving a subsidiary, are not treated as simply an application of general liability principles. The reason for the special treatment and attention that such claims receive stems from their potential to circumvent limits on veil piercing, as imposed by Adams and other cases, and-ultimately - their potential to undermine the principles of separate legal personality and limited liability. The inquiry in these cases is not so much on the parent company's

\footnotetext{
${ }^{28}$ Lungowe \& Others v. Vedanta Resources Plc \& Amor [2016] EWHC 975; [2017] EWCA Civ 1528.

29 His Royal Highness Okpabi v. Royal Dutch Shell plc [2017] EWHC 89 (TCC).

30 AAA et al v. Unilever and Unilever Tea Kenya Ltd. [2017] EWHC 371 (QB).

31 Okpabi v. Royal Dutch Shell Plc and Shell Petroleum Development Company of Nigeria Ltd [2018] EWCA Civ 191.
} 
wrongs directly vis-⿳亠丷⿵冂-vis a third party, but on the presence of actions or omissions that allegedly constitute a fault on the part of the parent company because they in turn resulted in actions or omissions at a subsidiary that harmed an employee or third party.

An important example for the potential effects and mechanics of modern approaches to parent company liability is provided in Chandler. Instead of relying on traditional piercing or claims that actions or omissions by parent company representatives were the immediate cause of the claimant's harm, it was a looser notion of the parent's control over its subsidiary that together with notions of proximity, fairness, and reliance ${ }^{32}$ led the Court to find a special relationship between the parent and the subsidiary's employee, resulting in the former's assumption of responsibility. In conjunction with the four-part test mentioned above, this gave rise to the parent's own liability.

The approach taken in Chandler was in various ways unsuitable for the facts at hand, but it is also of limited utility as a general basis for future decisions. First, it is unclear what type and level of control is needed to meet the court's requirement for there to be 'relevant control'. Chandler appears to indicate that a general practice of involvement in a subsidiary's trading operations is sufficient, even if these interventions are unrelated to the area that led to an injury. Apart from the lack of clarity and issues with causation, using 'control' in this manner is problematic because it is both over- and underinclusive. It is overinclusive because it includes in its ambit practices that are common in almost every corporate group, where there are at least some aspects that are subject to a uniform group policy; thus, almost every parent would satisfy this part of the test for liability. It is also underinclusive because the fact that a parent company failed to exercise control should not disqualify claims against it. A parent company that does not intervene in any way in its subsidiaries' business - including the type of 'pure' holding company that was the defendant in Renwick ${ }^{33}$ - may still be an appropriate defendant, as we will explain in further detail when we discuss the case for expanded group company liability below. Finally, control (as used in Chandler) as a prerequisite for liability is also bad policy as it may deter the development of desirable overarching group policies by parent companies that promote health, safety, or good financial and operational practices.

The other, more specific elements of Chandler's liability test are also problematic. While the first prong of the Chandler test's idea that the parent and subsidiary should be in the same business and thus form one enterprise has merit-although it should be defined quite differently from and more broadly than Chandler) - the other elements of the test are limited. Thus, the parent's superior knowledge on relevant aspects of health and safety in the industry and its knowledge of safety issues at the subsidiary are unnecessary requirements. If parent and group company liability is conceptualised as an effort to internalise business risks—which it should

\footnotetext{
32 Thompson v. The Renwick Group plc [2015] 2 BCC 855 suggests that reliance needs to occur on the part of the subsidiary and not the injured third party.

33 Ibid.
} 
be-then liability can be assigned without inquiring into the parent's state of mind, knowledge, and own actions.

At the same time, direct parent liability that is so remote that it appears to be disguised veil piercing or an attempt to circumvent the corporate shield is problematic_-not because it has the potential to overcome limited liability-but because in its current form it creates uncertainty and unduly stretches established tort principles. Indeed Chandler, with its references to the tort law concept of fairness, raises the question to what extent the finding of liability in this and other cases is influenced by policy and justice considerations. After all, it is understandable that courts would be sympathetic towards and would seek to facilitate claims brought by victims of corporate torts that would remain uncompensated but for a finding of parent company liability. Indeed, as will be expanded upon in the following section, such policy objectives are defensible and find support both on grounds of fairness as well as economic considerations. However, a test that is stretched and misguided is objectionable. Rather, there should be alternative, more principled means of holding parent companies_-and in fact entire group companies-liable that lead both to better outcomes for tort claimants and result in more ex ante legal certainty for potential defendants.

\section{The (Economic) Case for Group Company Liability}

Having discussed the demise of veil piercing and identified weaknesses in the emerging trend to hold parent companies directly liable based on their own misconduct, it becomes apparent that other approaches are needed. This is, of course, based on the assumption that expanding the liability of group companies is a desirable development. However, in outlining the case for expanded liability, the article focuses on the law and economics point of view concerning group liability. This is because although stakeholder theorists of corporate law will likely welcome group companies' increased liability towards third parties affected by a subsidiary company's tortious conduct, ${ }^{34}$ one would expect law and economics proponents to oppose this notion. However, this is not the case. Indeed, when it comes to group company liability, there is a convergence of opinion between stakeholderism and law and economics.

The starting point of this inquiry is the basic notion of companies' limited liability generally, that is outside of the group context. Limited liability has been considered by many commentators-from an efficiency perspective- to be welfare maximising for society as a whole. ${ }^{35}$ The main argument is that by reducing risks for shareholders, limited liability facilitates the aggregation of capital and encourages investment, which is especially helpful for large, capital intensive ventures. ${ }^{36}$ In addition, given the protections it provides to shareholders, limited liability (among other benefits)

\footnotetext{
34 See, e.g., Dine (2012); Skinner (2015), pp 1862-1863.

35 See Bainbridge and Henderson (2016).

36 Easterbrook and Fischel (1985), p 97; Bainbridge (2001); Posner (2007), p 425.
} 
reduces the time and resources that shareholders need to spend on monitoring the corporate agents that manage the companies in which they have invested, further encouraging diversified and passive investments. ${ }^{37}$ Limited liability is thus thought to have played an essential role in developing modern economic systems. ${ }^{38}$

Yet despite the numerous benefits it purportedly bestows, the idea of limited liability has also been subject to numerous criticisms. In particular, criticism has stemmed from the clash between tort law and corporate law principles that limited liability entails. ${ }^{39}$ While limited liability towards voluntary (contractual) creditors has not sparked major concerns, some commentators view the principle's effects towards involuntary creditors, in particular tort victims, as highly problematic, including as applied to corporate groups. ${ }^{40}$ Principally, these critics have noted that limited liability can externalize costs by imposing damages or losses caused by a corporation onto third parties or the public at large, instead of the shareholders, if a corporation's assets are insufficient to cover the losses. Moreover, while voluntary creditors can protect themselves through ex ante due diligence and negotiated protections and rewards, such as adjusted interest rates for lenders, this is not the case for involuntary creditors.

However, even among scholars who have advocated strongly in favour of limited liability, there are notable voices suggesting that the principle may be less appropriate or even wholly inappropriate in the group company context. The general thrust of these arguments is that the main economic reasons that justify limited liability for individual shareholders in a stand-along company do not normally apply-or not with the same force-to companies that hold shares in other companies. Blumberg, for instance, concluded that 'most, but not all, of the suggested arguments for limited liability simply do not apply to corporate groups, or at least are not always fully applicable'. ${ }^{41}$ This argument can be broken down into three broader objections.

First, it has been noted that allowing creditors to reach the assets of parent companies does not create unlimited liability for individual investors, which means that for them the benefits of diversification, liquidity, and monitoring by the capital market are unaffected even if limited liability were to be abolished for corporate shareholders. ${ }^{42}$ This insight then forms the basis for the argument that as long as the ultimate parent company's limited liability protects individual shareholders, these shareholders are unlikely to be less inclined to invest capital in business ventures, even if the individual ventures themselves do not benefit from additional layers of limited liability in their intra-group relations. Similarly, as long as the risk associated with the individual shareholders' investment in the ultimate parent company is capped by limited liability, they will also not need to increase their level of costly monitoring or involvement in managerial decisions.

\footnotetext{
37 Easterbrook and Fischel (1985), pp 94-98.

38 See, for example, Bainbridge (2001), pp 495-496.

39 For example, Alexander (1992); Gabaldon (1992); Glynn (2004); Fettet (1995).

40 See Lipton (2014), p 479.

41 Blumberg (1986), pp 623-626.

42 Easterbrook and Fischel (1991), pp 56-57; Bainbridge (2001), pp 526-534; Blumberg (1986), p 623.
} 
Second, it has been argued that considerations pertaining to monitoring and other agency costs, aggregation of capital, and diversification are far less important in the group company context. ${ }^{43}$ Parent companies are not in the position of an 'absentee owner' but can more easily monitor, manage, and access information from subsidiaries; the need for incentives encouraging widespread distribution of shares/investment does not apply at the level of the parent company (as opposed to the ultimate individual investors); and the issue of risk avoidance and diversification is less pertinent for parent companies compared to individual shareholders.

Third, commentators have opined that the moral-hazard problem stemming from limited liability is greater in parent-subsidiary situations, an issue of special importance in considering the corporation's role for the public. One reason for this is that managers of subsidiaries also tend to be (perhaps primarily) managers in the parent company and as such their continued employment at the parent company level diminishes the negative effects that they may personally experience in the case of a subsidiary's insolvency. ${ }^{44}$ This smaller exposure reduces managerial incentives to arrange suitable levels of insurance at the subsidiary level. Further, and more fundamentally, commentators have suggested that because of the imbalance between potentials risks and rewards, there is a heightened possibility that excessively risky activities within groups will be conducted through minimally capitalised subsidiaries, with potentially severe consequences for tort creditors. Specifically, groups can contractually structure their affairs in such a way that a thinly capitalised subsidiary can carry out operational activities (which could result in corporate torts) while the main assets are concentrated in the parent or other affiliated companies. ${ }^{45}$ In the same vein, Hansmann and Kraakman have argued that limited liability for companies 'cannot be rationalized' as it incentivizes subsidiaries to underspend on precautions to avoid accidents and can lead to overspending on hazardous activities. ${ }^{46}$ They also posit that while unlimited liability puts shareholders in the position of an insurer, this is particularly justified in the case of corporate shareholders given their superior ability to avoid costs and bear risks. ${ }^{47}$ This leads them ultimately to argue in favour of a system of pro rata shareholder liability for torts.

Leebron's nuanced study of limited liability-which distinguishes between wholly-owned corporate groups and corporate groups with partial ownership-also argues in favour of rejecting limited liability for groups in certain cases. ${ }^{48}$ In the case of wholly-owned groups, irrespective of whether a group company is an integrated company with operational activities or solely a holding company, Leebron finds that limited liability should not apply. As he explains, investments in integrated companies do not represent a diversification of risk and hence should not benefit from limited liability, while true risk diversification through a conglomerate structure does

\footnotetext{
43 Blumberg (1986), pp 624-626.

44 Easterbrook and Fischel (1991), pp 56-57.

45 Ibid.; Bainbridge (2001), pp 529-531, referring to LoPucki (1998).

46 Hansmann and Kraakman (1991), pp 1880-1885.

47 Ibid., pp 1916-1919.

48 Leebron (1991).
} 
not deserve it either 'since shareholders can achieve such diversification on their own'. ${ }^{49}$ While considering that there may be a case for allowing group structures as a means to diversify managerial risks, Leebron concludes that this is undesirable in cases of catastrophic losses to tort claimants and unlimited liability may help align managerial interests with those of society. ${ }^{50}$

Leebron then moves on to examine group companies that are not wholly-owned by another company, but where in addition to a parent company there are other (individual or corporate) shareholders. ${ }^{51}$ If unlimited liability would only apply to wholly-owned companies, it would be easy to avoid this regime by adding a small number of outside shareholders to each group company. But if unlimited liability also were to apply to partially owned companies, the question is how the law should define the term subsidiary-with the particular problem of how to account for shareholdings by financial intermediaries — and how liability should be allocated between the shareholders. Seeking a pragmatic solution, Leebron proposes unlimited liability for tort claims among companies that are connected through majority positions in shares, where parents are liable for subsidiaries and vice versa, and with tort claimants being granted priority over financial creditors throughout the group.

\section{Reforming Liability for Group Companies}

Given the longstanding recognition of the problematic nature and effects of limited liability within group companies, it is not surprising that significant efforts have been put forward to address these limitations. While practical developments in this area have been largely driven by courts that responded to and refined theories of liability raised by claimants, the issue of group company liability has also piqued considerable interest by legal scholars and led to various proposals on legal reform, including in a proposed UN-sanctioned business and human rights treaty, which may include a component specifying the parameters of group company liability. ${ }^{52}$

In this part, the focus is on five categories of potential approaches to reforming group company liability. These include: specifying and clarifying areas in which corporate veil piercing is permissible; statutory liability based on a direct duty of care for parent companies; the concept of rebuttable or presumed liability for group companies; recognition of the principle of enterprise liability; and disregarding or modifying shareholders' limited liability through changes in corporate law and/or insolvency law. The aim is to explore and understand these approaches as a means of proposing reforms in this area.

\footnotetext{
49 Ibid., p 1617.

50 Ibid.

51 Ibid., pp 1620-1623.

52 Deva (2015).
} 


\subsection{Clarify and Improve Veil Piercing}

A first option for reforming group company liability is through continued reliance on veil piercing, with the expectation that the tools for piercing would be improved through further specification and clarification of the grounds under which piercing is permitted. The exceptions for veil piercing would ideally apply uniformly across borders, which could be accomplished either by specifying these grounds in an international treaty or in a model law.

While options based on veil piercing have the benefit that there is a wealth of case law and academic commentary that can be used as a basis to improve this tool, ${ }^{53}$ piercing likely represents the least desirable way forward. The merits of veil piercing are limited and it is unlikely that this doctrine's known weaknesses can be overcome in a satisfactory manner and to a degree that it can serve as the principal mechanism for addressing the problem of group company liability. Veil piercing involves disputes over difficult questions of fact and law with concepts including 'façade' and 'equity' that are not only open to interpretation but may also lead to complex litigation. ${ }^{54}$ It is unlikely that veil piercing will simplify redress for tort victims as the different grounds are difficult to clearly delineate and prove. In addition, welladvised companies will likely be able to circumvent veil piercing requirements and, in any event, veil piercing as normally applied between a company/subsidiary and its shareholder/parent are not helpful where assets of members of a corporate group other than parent companies (such as sister companies) must be reached to satisfy debts. The limited utility of veil piercing thus prompts the need to seek solutions for parent/group liability elsewhere.

\subsection{The Parent's Duty of Care}

A second option is to implement the direct duty of care approach and its preconditions, laid down in Chandler and a number of other cases decided in foreign jurisdictions, on a statutory basis. However, as already discussed in more detail above, the direct duty of care approach is limited—often even highly flawed — and does by itself not represent a sufficient solution to address the liability of corporate groups. Determining the precise scope and contents of a parent company's duty of care is difficult and courts may be tempted to unduly stretch the boundaries of tort law in order to arrive at a desired result.

In short, weaknesses of approaches relying on a parent company's own duties include that it raises the question of how to define the necessary level and nature of control that will result in a duty and may trigger liability; that it tends to depend on the parent's own state of mind or knowledge of certain items such as health and safety issues at the subsidiary; that it can be circumvented by the parent transforming itself into a holding company as in Renwick; and that it may rely_and in the UK

\footnotetext{
53 For example, Lee (2015); Oh (2013); Cheng (2010); Anderson (2009); Moore (2006).

54 See Muchlinski (2007), p 315; Deva (2015), p 3.
} 
indeed does rely according to the approach accepted in Chandler-on the concept of assumption of responsibility. Assumption of responsibility however is for various reasons often ill-suited to serve as a basis for parent company liability. ${ }^{55}$ Using direct duties of corporate parents as a basis for group company liability also does not fare much better than veil piercing in terms of legal certainty or avoidance of complex litigation. Furthermore, even if more refined tests are introduced to impose direct duties on parent companies, this would not address problems for tort victims where group company assets are concentrated not in a parent company but in other subsidiaries (sister companies or affiliated companies). Under current case lawwith the exception of one singular case ${ }^{56}$ - it is unlikely that these companies will be found to owe duties to third parties affected by activities at another subsidiary.

\subsection{Presumption of Liability}

A third option is the introduction of a rebuttable presumption of parent company liability for subsidiaries. In case of harm to third parties emanating from a subsidiary, the parent would thus bear the onus of demonstrating that it should not be responsible to the third party victims. This is the approach favoured by the Committee working on the proposed Business and Human Rights treaty and it has, separately, also garnered interest or come to fruition in certain jurisdictions. ${ }^{57}$ The UN committee, for instance, suggests that the system of presumption be based on proof that '[t]he parent company [...] did not know (or had no reasons to know)' about the infractions in question 'or that the violations took place despite the parent company taking appropriate preventive and redressive due diligence steps' ${ }^{58}$

In France, a newly introduced statutory duty of vigilance now requires certain corporations to take reasonable care in identifying and preventing risks to human rights and fundamental freedoms, serious bodily injury or environmental damage or health risks resulting directly or indirectly from the operations of the company. ${ }^{59}$ The vigilance obligations are relevant for group liability as they extend to subsidiaries (controlled companies) as well as subcontractors or suppliers. Similarly, a popular initiative 'for responsible enterprises' in Switzerland proposes a due diligence obligation on companies to respect human rights and environmental standards. ${ }^{60}$ If accepted, this duty would require companies to identify real and potential impacts on internationally recognized human rights and the environment; take appropriate measures to prevent violation of these standards, and account for the actions taken. This obligation extends to both the parent company as well as any domestic and

\footnotetext{
55 On this see Petrin (2013).

56 Newton-Sealey v. ArmorGroup Services Ltd. [2008] EWHC 233 (QB).

57 See Deva (2015), p 4; Muchlinski (2010), pp 923-924; Muchlinski (2007), p 322.

58 Deva (2015), p 4.

59 The law applies to corporations with more than 5000 employees with a registered office in France.

60 Popular initiative 'For responsible enterprises-for the protection of humans and the environment (enterprise responsibility initiative)' (authors' translation). For official information on the initiative, see www.bj.admin.ch/bj/de/home/wirtschaft/gesetzgebung/konzernverantwortungsinitiative.html (last visited 26 January 2018).
} 
foreign companies it controls. Both the French law and the Swiss initiative aim to hold companies liable for failure to adhere to the delineated obligations unless the company can demonstrate that it took due care, for which it bears the onus of proof.

From the victims' perspective, approaches that place a duty on corporations and shift the burden on them to show that they did not breach their obligations obviously facilitates the process for them. ${ }^{61}$ However, upon examining the various iterations of the 'presumption' approach it also becomes clear that it is very similar to liability based on parent companies' own duties of care, with the main difference being that the burden of proof is shifted to the defendant company. For this reason, the actual approach itself fundamentally still suffers from the same or similar problems that were identified and discussed in the context of Chandler and parents' direct duties of care. Principally, it still remains unclear why liability should (exclusively) depend on 'ineffective control', lack of knowledge, or other omissions on the part of the parent company, given the convincing case for broader liability of corporate shareholders independent of such factors, which are more akin to strict enterprise liability.

\subsection{Enterprise Liability}

Another option for reform consists of moving towards a form of "enterprise liability'. Although there is no singular definition of this term, enterprise liability is often equated with treating all companies in a group as a single enterprise and holding the single enterprise responsible for harm caused by any individual company within the group. This negates the separate legal personality of related corporate entities and allows for both horizontal and vertical piercing - that is directing claims against parent and/or sister companies. This approach is thought to bring the 'legal reality of corporate groups closer to their economic reality' and to force group companies to assess business activities that are potentially harmful for third parties 'holistically for the entire group, rather than move risky or hazardous businesses to distant or under-funded subsidiaries' ${ }^{62}$

In the UK, enterprise liability had a short-lived appearance when Lord Denning championed it in the form of the 'single economic unity' theory in DHN Food Distributors v. Tower Hamlets. ${ }^{63}$ However, Denning's single economic unit approach did not gain acceptance as a general principle for veil piercing.

In several other jurisdictions, however, certain forms of enterprise liability are recognised. ${ }^{64}$ For instance, in the US creditors can reach the collective assets of all of the corporations making up the enterprise under certain circumstances and according to some courts. ${ }^{65}$ The enterprise liability doctrine thus acts as a supplementary doctrine to veil piercing (which applies between parents and subsidiaries and governs 'vertical' liability) by enabling courts to hold a company that is part of

\footnotetext{
61 Deva (2015), p 4.

62 Deva (2015), p 3.

63 [1976] 1 WLR 852.

64 Dearborn (2009), pp 220-230.

65 Bainbridge and Henderson (2016), p 192. See also Strasser (2005), pp 646-647.
} 
a corporate group liable for the debts of a sister company, or 'horizontal' liability. Enterprise liability is therefore particularly useful where a subsidiary company is unable to satisfy debts or claims but the corporate group as a whole, but not necessarily the insolvent company's parent company, has sufficient assets.

The test for enterprise liability as developed by certain US courts tends to consist of two elements. First, there has to be such a high degree of unity between the entities in question that their separate existence has de facto ceased. Second, in light of this unity, treating the entities as separate would promote injustice. ${ }^{66}$ Although courts have taken differing approaches to interpreting the precise requirements under this test, elements that show how the separateness of the group entities was disregarded (such as intermingling of assets or other evidence that they were not treated as independent entities) as well as an improper fraudulent motive for using group structures is normally required. ${ }^{67}$

In Germany, the Konzernrecht (law of corporate groups) provides for a distinct regime of corporate group liability - this is in contrast to EU law, where proposals for the purpose of developing a common body of law for corporate groups were developed in the 1970s but did not come to fruition. It provides among others, in short, a contractual (optional) and a mandatory model applicable to de facto groups, which both provide for instances of the parent's or dominating company's liability. ${ }^{68}$ German law recognizes group companies in this manner in an effort to address the inherent conflict of interest that exists between parents and their subsidiaries, which could benefit the parent's shareholders at the expense of the subsidiary's shareholders and creditors. However, this also means that the Konzernrecht regime is mostly geared towards the protection of minority shareholders and contractual creditors, not victims of torts or human rights violations that are the focus of the present inquiry.

India has similarly made efforts at recognizing enterprise liability, although only in a narrow set of circumstances. After the Bhopal disaster in which a gas leak by an American parent company's subsidiary caused widespread injuries and deaths in Bhopal, India, the Indian government argued in the ensuing case that a multinational enterprise should 'necessarily assume responsibility' for harms caused by it 'for it alone has the resources to discover and guard against hazards and to provide warnings of potential hazards' ${ }^{69}$ The Indian Supreme Court later recognised this argument by holding that:

[A]n enterprise [...] engaged in a hazardous or inherently dangerous industry [...] owes an absolute and non-delegable duty to the community that no harm results to any one on account of the dangerous nature of the activity it has undertaken [...] If the enterprise is permitted to carry on the hazardous or

\footnotetext{
66 See, e.g., Pan Pacific Sash \& Door Co. v. Greendale Park, Inc., 166 Cal. App. 2d 652 (1958) and its progeny.

67 Bainbridge and Henderson (2016), pp 191-199.

68 See Engrácia Antunes (2017), pp 8-12; Reich-Graefe (2005); Davies et al. (2012), pp 245-247.

69 Indian government's complaint before the US District Court, Southern District of New York (8 April 1985), cited in Muchlinski (2007), p 319.
} 
inherently dangerous activity for its profit, the law must presume that such permission is conditional on the enterprise absorbing the cost of any accident. ${ }^{70}$

This doctrine became subsequently accepted as defining enterprise liability in India, although only with respect to corporations engaged in hazardous or inherently dangerous industries.

Enterprise liability, in varying forms, has also received a great deal of interest in the academic literature. A number of scholars have analysed limited liability between parent and subsidiary companies from a law and economics perspective and found that there is only weak support for it, which has led some commentators to argue in favour of enterprise liability mechanisms. Bainbridge has found that the prospect of judgment-proofing within groups means that parent company liability alone is insufficient and that enterprise liability theories appear better suited, although not ideal, to deal with large-scale risk-externalizing. ${ }^{71}$ Blumberg, one of the leading proponents of the enterprise conception of corporate groups, has suggested that such groups are characterized by the unifying factors of control and economic interrelationship. While Blumberg acknowledges the relevance of added elements such as administrative and financial interdependence, integration of employee relationships, and use of a common group persona, ${ }^{72}$ control remains the central tenet of conceptualizing corporate groups and as such, according to Blumberg, accordingly also justifies a 'control-based form of enterprise liability'. ${ }^{73}$

In recent years, notable scholarly proposals building upon enterprise liability concepts have also been outlined by other commentators. Skinner suggests, for instance, that parent company liability be imposed through a statutory enactment for violations of customary international human rights and serious environmental torts. ${ }^{74}$ However, she limits her suggestion of imposing statutory liability to corporations operating as part of a unified economic enterprise in 'high risk host countries'. ${ }^{75}$ Conversely, Dearborn proposes a model of enterprise liability that requires an economically integrated enterprise, which is defined on a case specific 'inquiry of economic, and not behavioral, control'; and an instance of a mass tort, human rights violation, or environmental harm. ${ }^{76}$

\subsection{Disregard or Modify Limited Liability}

Finally, the problem of group company liability could be addressed through changes in corporate law rules that govern limited liability as well as by adjusting relevant insolvency rules. In its most radical form, the solution to problems of group liability

\footnotetext{
70 MC. Mehta v. Shriram Food and Fertilizer Industries (Oleum Gas Leak), AIR 1987 SC 1965.

71 Bainbridge (2001), pp 529-531.

72 Blumberg (1993), pp 245-246; Blumberg (2005). See also Orts (2013), p 146; Dine (2012) (discussing Albania's enterprise liability).

73 Dearborn (2009), p 231.

74 Skinner (2015), p 1849.

75 Ibid.

76 Dearborn (2009), p 252.
} 
would lie in complete abolition of limited liability for voluntary and involuntary claims. ${ }^{77}$ Less drastic solutions would see limited liability being abolished for tort claims in groups that are wholly-owned or connected through majority positions groups ${ }^{78}$ liability for torts and statutory violations being imposed for shareholders that have the capacity to control corporate activity ${ }^{79}$; abolishing limited liability in closely-held companies ${ }^{80}$; making limited liability contingent upon financially responsible conduct of controlling shareholders ${ }^{81}$; disregarding limited liability for corporate shareholders "when the corporate arrangement has increased risks over what they would be if firms generally were organized as separate ventures' ${ }^{82}$; and adopting a system of pro rata shareholder liability for torts. ${ }^{83}$

Modification of limited liability rules is equally a central theme in a new leading book on group liability. Christian Witting proposes a two-pronged approach for dealing with claims in corporate groups and networks. The first prong of his test for liability consists of statutory modifications to achieve modified limited liability. This would apply when a company becomes insolvent and there are unsatisfied personal injury claims against it. In these instances, both the parent company and individual shareholders in the insolvent company would become liable, pro rata, in an unlimited amount for those personal injury claims ${ }^{84}$ In addition, the personal injury claims would be prioritized - ahead of both secured creditors and other unsecured creditors-in winding-up or corporate insolvency procedures. ${ }^{85}$

Witting's second proposed liability prong is directed at network companies, where liability through shareholders' modified limited liability may not apply or prove insufficient. ${ }^{86}$ For these instances, he proposes introducing a new tort of 'multiple entity recklessness', which would apply when a company acts in a way which is objectively reckless in undertaking physical processes which give rise to significant risks of injury. In these instances, liability could be extended to other companies having significant commercial relationships ${ }^{87}$ with the risk-taking company and its reckless conduct. Each would become prima facie jointly liable with the risk-taking company for personal injury claims on the basis of their deemed agreement. It would then be up to the prima facie liable parties to prove that they took every step to avoid the future causation of personal injury to others by doing such things as

\footnotetext{
77 Muchlinski (2010), p 925 (referring to a proposal by Rothbard).

78 Leebron (1991).

79 Mendelson (2002), pp 1271-1272.

${ }^{80}$ Halpern et al. (1980), pp 148-149.

81 Millon (2007). See also Engrácia Antunes (1994), pp 396-406.

82 Easterbrook and Fischel (1991), p 57.

83 Hansmann and Kraakman (1991).

84 Witting (2018), p 420.

85 Ibid.

${ }^{86}$ Ibid., p 421.

87 This involves the other companies having an explicit agreement with the first company or where they pursue a common objective. Ibid., p 383.
} 
blowing the whistle on the reckless conduct and ceasing coordination with the riskcreating company. ${ }^{88}$

\section{Two-Tiered Strict Liability Based on Risk Internalization}

Having reviewed the leading reform options, and based on the convincing twin case of increased group company liability from both a stakeholderist as well as an economic viewpoint, this article argues in favour of a combined system of enterprise liability for traditional corporate groups with a form of adjusted or modified vicarious liability of companies and groups for 'network' companies. ${ }^{89}$ To be clear, the proposals outlined in the following sections are directed at reforming parent company and group company liability, they do not pertain to individual shareholders' liability.

\subsection{Enterprise Liability for Traditional Groups}

Corporate shareholders should not be able to invoke limited liability when it comes to claims by tort victims that were affected by actions stemming from a subsidiary. Indeed, to avoid the possibility of risk-shifting within groups, if a subsidiary is unable to satisfy claims against it, tort victims - as opposed to those in a voluntary contractual relationship with corporations - should have redress against the entire group and any individual company that forms part of that group. This liability should extend beyond the parent company and include the group as a whole. Apart from risk compartmentalization as a shielding device against extra-contractual claims, however, the various benefits of corporate group structures can and should be preserved.

The enterprise liability approach offers more promise than the proposals suggesting abolishing or limiting limited liability for several reasons. First, exempting individual shareholders from limited liability — whether it is pro rata or not—can be an untenable and potentially dangerous deterrent to investment and entrepreneurial activity, despite commentators' efforts to diffuse this concern. ${ }^{90}$ In addition, at the risk of stating the obvious, limited liability for individual shareholders is far from a system where individuals are free from liability. When it comes to instances such as mass torts that lead to their company's insolvency, individual shareholders investors stand to lose their entire contributed capital, which for many retail investors may already represent a substantial wealth loss even in the absence of additional personal liability over and above this amount. Further, while the idea of abolishing

\footnotetext{
88 Ibid., p 422.

89 Enterprise liability as proposed herein does not stand in isolation. It is supplemented by other legal tools, including direct tortious liability of companies and corporate agents as well as rules that provide remedies in case of an entity's insolvency, such as rules on preferences, transfers, and fraudulent or wrongful trading.

${ }^{90}$ For counterarguments supporting individual shareholders' liability, see Witting (2018), p 276.
} 
limited liability for corporate shareholders and, specifically, parent companies within groups is not per se an idea without merit, the weakness of this approach is that it does not allow, in and of itself, tort victims to reach the assets of sister companies. Accordingly, it may not adequately counter instances of judgment proofing within groups. Finally, concepts that limit or modify limited liability are inferior to enterprise liability approaches when considering the causality of wrongs that stem from group activities. Typical group structures include strongly interconnected entities (in operational, financial, strategic, and other matters) and may feature top-down instructions and control. In these structures, it may be difficult, if not arbitrary, to pinpoint a single entity whose behaviour is the clear cause of a third party's loss. Instead, the group as a whole is more likely responsible, supporting the view of an enterprise conception of groups.

Thus, using enterprise liability as a base for a reformed liability approach, this article argues in favour of a model that uses equity ownership and voting rights to establish the existence of a group (on which see below) but is otherwise independent of whether control existed and was or was not properly exercised. ${ }^{91}$ Similarly, liability should not depend on improper motives, wrongdoing and other subjective aspects. Even the level of capitalization (thin capitalization or under-capitalization) — which according to some enterprise liability approaches is required for group liability — should not be decisive. Instead of relying on control and (mis)behaviour of a parent or controlling entity, a group's liability for one of its member companies' torts should be conceptualized as a cost of doing business, which-according to economic theory and in line with social considerations - should be internalised. Indeed, the idea of internalization or risk alignment is inherent to enterprise liability thinking. ${ }^{92}$ It has also long been an overarching principle of vicarious liability and corporate liability generally that the benefits of doing business have to be aligned with the costs of doing so, including liability to third parties.

As a broader movement in the US, enterprise liability gave birth to strict products liability and other forms of expansive and no-fault liability. The underlying consideration of 'you profit, you pay' 93 can be applied not only to single entities, but equally to corporate groups pursuing a common goal. The entire group benefits from the existence and activities of group structures and there is a mutual benefit between the various companies that together form the group. This also suggests that the group should bear the full costs that flow from operating a business that utilizes a group structure-specifically externalities that arise when a subsidiary is unable to fully compensate third parties for torts that stem from its activities. In light of this consideration, it is unnecessary to distinguish between different kinds of tortious acts and, for instance, allow enterprise liability only for mass torts, human rights violations,

\footnotetext{
91 Witting (2018), pp 282-287 has convincingly made the case against control as the basis for group liability.

92 See Dearborn (2009), pp 210-212; Witting (2018), p 290; Morgan (2015), pp 290-291; Ramsay (1999), p 373. Beyond economics-based considerations, Skinner translates the benefits derived from subsidiaries into an ethical obligation on the part of parent companies to compensate victims of human rights violations stemming from subsidiary operations. Skinner (2015), pp 1807-1809.

93 Dearborn (2009), p 200.
} 
personal injury, or environmental harm as some reform proposals have suggested. ${ }^{94}$ Internalisation of any liability costs is desirable, independent of their precise nature and scale. Additionally, the corporate group will normally be in a better position than tort victims to bear the losses that are caused by one of its members' torts. In economic terms, this speaks to a party's ability to absorb or bear risks. As Muchlinski has noted, the corporation, rather than involuntary creditors, should bear the risk since the risk is created by the corporation that 'profits from the activities giving rise to the risk'. Internalisation is not the current legislative position, however, and achieving it in the manner suggested herein would necessitate statutory changes. ${ }^{95}$

Perhaps the biggest problem facing enterprise liability approaches is to find an appropriate definition of what constitutes the enterprise and, relatedly, which companies should be liable within the group or how such liability is to be allocated among them. A possible approach is to adopt the definition of holding company and subsidiary provided in Section 1159(1) of the Companies Act 2006. It notes that a relationship of holding company and subsidiary exists between companies where the former has majority voting rights, the right to control the majority of the board composition or the majority voting rights in the latter, or where the latter is a subsidiary of a company that itself is a subsidiary of that holding company. Holding companies and subsidiaries that are connected in this manner would thus form a group for the purposes of enterprise liability. Alternatively, the basis for establishing the existence of a group company could rely solely on the existence of controlling equity stakes between parent and subsidiary companies, with the size or threshold for finding a 'controlling' stake to be defined by a fixed percentage (instead of an ad hoc basis in view of specific facts) in order to provide clarity. Of course, the existence of an 'enterprise' (as defined above) as a pre-condition of liability means that there is no recovery in its absence. We do not, however, regard this as problematic as, first, there are no grounds for internalisation in the absence of an enterprise and second, because we propose to fill certain gaps by way of the additional tier of liability outlined in the next section.

\section{2 'Vicarious Liability' for Non-Traditional Groups (Involving Network Companies)}

Defining the group company solely in the manner as described above fails to address situations where entities can be said to be sufficiently connected even in the absence of equity ownership or rights to control voting or board composition. For example, a single company or a group company could have a deep contractual relationship with another company-such as in the case of a mutually exclusive supplier-customer relationship_but without any equity interests on either side. This is the problem of corporate networks mentioned at the outset. While networks normally lack the same level of 'groupness' as traditional groups, ${ }^{96}$ they may nonetheless be connected and

\footnotetext{
94 See Ibid., p 252; Skinner (2015); Witting (2018), p 288.

95 Muchlinski (2010), p 923.

96 See Witting (2018), p 173.
} 
pursue a common economic goal with another company or entire group to a degree that makes it appropriate to treat them as a non-traditional group or enterprise and extended liability beyond the single entity approach. Specifically, looking at this question once more through a cost-benefit and cost internalization prism, the network company scenarios also warrant broader liability in the case of torts, going beyond isolated liability of individual companies. Closely connected entities that are pursuing and benefiting from coordinated business efforts should also have to collectively bear the risks for third parties that flow from their mutual cooperation.

However, an assessment whether relations between companies that do not meet equity or voting-related tests amount to the formation of a non-traditional group for tort liability purposes would have to be conducted on a case-by-case basis. Also, applying the model of allowing tort victims to hold any group member liable for torts committed by another group member may lead to overly far-reaching results in the case of network companies/non-traditional groups. Specifically, while it may be justifiable to hold a corporate group liable for torts by one of its suppliers that appears to be a network company (abusive working conditions at the supplier would be an example), it may not be justifiable in turn to hold the supplier liable for torts committed by one of the companies that make up the customer's group company. In case of looser and less formalized non-traditional groups that involve network companies, the question of liability should be answered based on integration. In the customer-supplier example mentioned above, it may be that the supplier is integrated in the customer's business but not vice versa. This would entail the customer's responsibility (and the customer may be a single company or an entire traditional group) for the supplier's tort but there would be no liability in the other direction, that is no liability on the part of the supplier (network company) for the customer.

Instead, for scenarios such as the customer-supplier or other relationship that suggest strong ties between two or more businesses or a traditional group and another business, liability of a company or traditional group of companies based on a modern iteration of vicarious liability tailored to the context of connected business entities should be allowed. Hence, a company or entire group should be liable for torts of a more loosely affiliated network company if there is a sufficient degree of integration based on an analysis of the totality of economic, organisational, and legal links between the entities. ${ }^{97}$ Guiding questions based on factors proposed by Dearborn (pertaining to the definition of groups) could be helpful in this regard, including whether a company furthers the economic goals or business of another company/group; is functionally part of another company/group's business; or serves the purpose of externalizing another company/group's liability. ${ }^{98}$ Additionally, and as part of this inquiry, an element analogous to classic vicarious liability's 'course of employment' requirement would have to be considered. This could consist of

\footnotetext{
97 A similar test was applied, in the parent-subsidiary context, by the Court of Justice of the European Union in Case C-97/08 P, Akzo Nobel NV v. Commission of the European Communities [2009] ECR I-08,237; [2009] 5 CMLR 23.

98 Dearborn (2009), p 252-253.
} 
assessing whether tortious conduct occurred in the course of coordinated business conduct between a company/group and a network company.

English courts have been reluctant to apply vicarious liability in the parent-subsidiary relationship. Nevertheless, two scholars have suggested that in light of recent developments vicarious liability law might allow for this doctrine to become amenable for application in the corporate/group context. ${ }^{99}$ Indeed, foreign jurisdictions have already used or contemplated the use of vicarious liability in this context and it has also long been recognized in the field of competition law (where fines for acts of subsidiaries can be imposed upon a parent). ${ }^{100}$ Although liability for network companies based on establishing a group or enterprise through integration has disadvantages - it lacks ex ante certainty on whether a group has been formed and can attract criticism of being open-ended, meandering through entire economies ${ }^{101}$ —it appears necessary as a way to properly deal with the widespread economic reality of business structures that go beyond traditional notions of a group company.

\subsection{Some Limitations}

To be sure, enhanced group company liability may have consequences that are difficult to foresee. As Bainbridge and Henderson suggest, unlimited liability for controlling corporate shareholders might initiate a trend back to previously popular highly diversified corporate conglomerates, which based on newer evidence may not be a desirable development. ${ }^{102}$ Conversely, there could also be the opposite effect, with groups reducing diversification in order to avoid liability contamination stemming from one activity or industry that they are invested in onto another in a bid to avoid spill-over liability from risky to less risky areas. Further, if general unlimited liability for parent companies would cause high-risk business to be conducted by smaller businesses without group structures, ${ }^{103}$ then tort victims would be worse off. This is true because it would leave offending companies with smaller pools of assets and limited liability, because without group structures the company would have only individual shareholders that remain protected by the corporate shield. Still, given that liability insulation is not the only benefit of group structures ${ }^{104}$ and in light of some jurisdictions' requirements that business be conducted through local companies, it is unlikely that group structures would disappear entirely. ${ }^{105}$ This problem would also be mitigated-through the proposal for liability for network companies - since a lack of group structures would not per se exclude the possibility of liability for other entities. Finally, if enterprise liability allows claimants to direct

\footnotetext{
99 Morgan (2015), p 288-299; Witting (2018), pp 398, 18-19, 416.

100 See Nygh (2002), p 66; Rands (1999), pp 443-446; Hofstetter (1990), p 591; Witting (2018), p 400; Morgan (2015), p 288.

101 See LoPucki (1998), p 158.

102 Bainbridge and Henderson (2016).

103 As suggested by Easterbrook and Fischel (1985), p 111.

104 See Leebron (1991), p 1614.

105 As Leebron noted, as long as the benefits to having a group structure exceed the increased liability exposure related to subsidiaries' activities, then corporations will opt for such structures. Ibid., p 1615.
} 
their claims against one or several parent or subsidiary companies of their choosing (joint and several liability), this might result in negative effects on the affected entities' existing creditors and minority shareholders. It appears however difficult to avoid such issues without introducing complex additional provisions that allocate liability within groups and potentially necessitates revised priorities for enterprise liability tort claims in insolvency.

\section{Conclusion}

Group companies have an increasingly difficult time insulating themselves from liabilities incurred at the subsidiary level. Although courts frequently state that they do not pierce the corporate veil, the emerging trend to broaden corporate parents' direct liability towards third parties that suffered tortious loss due to a subsidiary's conduct has the same result. In fact, establishing parent company or group company liability for the acts of subsidiaries, which was once viewed as a 'political non-starter' 106 may now be a real and definite possibility. This is a welcome outcome given that it justifiably enhances duties and accountability of corporate groups to the public, which finds solid support both based on economic views of group liability as well as stakeholderist or pluralist perspectives on the corporate purpose. Indeed, the support for enhanced liability from these normally diametrically opposed schools of thought is an encouraging, albeit rare, convergence of opinion and outcomes in corporate law scholarship.

Open Access This article is distributed under the terms of the Creative Commons Attribution 4.0 International License (http://creativecommons.org/licenses/by/4.0/), which permits unrestricted use, distribution, and reproduction in any medium, provided you give appropriate credit to the original author(s) and the source, provide a link to the Creative Commons license, and indicate if changes were made.

\section{References}

Alexander JC (1992) Unlimited shareholder liability through a procedural lens. Harv Law Rev 106:387-445

Anderson HM (2009) Piercing the veil on corporate groups in Australia: the case for reform. Melb Univ Law Rev 33(2):333-367

Bainbridge SM (2001) Abolishing veil piercing. J Corp Law 26:479-536

Bainbridge SM, Henderson MT (2016) Limited liability: a legal and economic analysis. Edward Elgar, Cheltenham

Blumberg PI (1986) Limited liability and corporate groups. J Corp Law 11:573-631

Blumberg PI (1993) The multinational challenge to corporation law: the search for a new corporate personality. Oxford University Press, Oxford

Blumberg PI (2005) The transformation of modern corporation law: the law of corporate groups. Conn Law Rev 37:605-618

Cheng TK (2010) Form and substance of the doctrine of piercing the corporate veil. Miss Law J $80: 497-586$

106 Bainbridge (2001), p 531. 
Davies P et al (2012) Gower and Davies principles of modern company law, 9th edn. Sweet \& Maxwell, London

Dearborn M (2009) Enterprise liability: reviewing and revitalizing liability for corporate groups. Calif Law Rev 97:195-262

Deva S (2015) Briefing paper for consultation: parent company liability. https://www.escr-net.org/sites /default/files/parent_company_liability_briefing_paper_first_draft_sept_2015_-_eng.pdf. Accessed 11 Oct 2018

Dignam A, Lowry J (2014) Company law, 8th edn. Oxford University Press, Oxford

Dine J (2012) Jurisdictional arbitrage by multinational companies: a national law solution? J Hum Rights Environ 3:44-69

Easterbrook FH, Fischel DR (1985) Limited liability and the corporation. Univ Chic Law Rev 52:89-117

Easterbrook FH, Fischel DR (1991) The economic structure of corporate law. Harvard University Press, Cambridge

Engrácia Antunes J (1994) Liability of corporate groups: autonomy and control in parent-subsidiary relationships in US, German and EU law. Kluwer Law International, Alphen aan den Rijn

Engrácia Antunes J (2017) New avenues on intragroup liability (February 28, 2017). English translation of 'Neue Wege im Konzernhaftungsrecht. Nochmals: Der “Amoco Cadiz”-Fall', in: Festschrift für Marcus Lutter zum 70. Geburtstag-Deutsches und europäisches Gesellschafts-, Konzernund Kapitalmarktrecht, Verlag Otto Schmidt, Cologne 2000, p 995-1009. https://ssrn.com/abstr act=2925129. Accessed 27 Sept 2018

Fettet B (1995) Limited liability-a principle for the 21st century? Curr Leg Probl (Part 2: Collected Papers) 48:125-159

Gabaldon TA (1992) The lemonade stand: feminists and other reflections on the limited liability of corporate shareholders. Vanderbilt Law Rev 45:1387-1456

Glynn TP (2004) Beyond 'unlimiting' shareholder liability: vicarious tort liability for corporate officers. Vanderbilt Law Rev 57:329-433

Halpern P et al (1980) An economic analysis of limited liability in corporation law. Univ Tor Law J 30:117-150

Hannigan B (2016) Company law, 4th edn. Oxford University Press, Oxford

Hansmann H, Kraakman R (1991) Toward unlimited shareholder liability for corporate torts. Yale Law J 100:1879-1990

Hofstetter K (1990) Parent responsibility for subsidiary corporations: evaluating European trends. Int Comp Law Q 39:576-598

Lee PW (2015) The enigma of veil-piercing. Int Co Commer Law Rev 26:28-34

Leebron DW (1991) Limited liability, tort victims, and creditors. Columbia Law Rev 91:1565-1650

Lipton P (2014) The mythology of Salomon's case and the law dealing with the tort liabilities of corporate groups: an historical perspective. Monash Univ Law Rev 40:452-487

Lo SHC (2017) Piercing of the corporate veil for evasion of tort obligations. Common Law World Rev 46:42-60

LoPucki ML (1996) The death of liability. Yale Law J 106:1-92

LoPucki ML (1998) The essential structure of judgment proofing. Stanf Law Rev 51:147-160

Mendelson NA (2002) A control-based approach to shareholder liability for corporate torts. Columbia Law Rev 102:1203-1303

Millon D (2007) Piercing the corporate veil, financial responsibility, and the limits of limited liability. Emory Law J 56:1305-1382

Moore MT (2006) 'A temple built on faulty foundations': piercing the corporate veil and the legacy of Salomon v. Salomon. J Bus Law 2006(3):180-203

Morgan P (2015) Vicarious liability for group companies: the final frontier of vicarious liability? J Prof Negligence 31:276-299

Muchlinski PT (2007) Multinational enterprises and the law. Oxford University Press, Oxford

Muchlinski PT (2010) Limited liability and multinational enterprises: a case for reform? Camb J Econ 34:915-928

Nygh P (2002) The liability of multi-national corporations for the torts of their subsidiaries. Euro Bus Organ Law Rev 3:51-81

Oh P (2013) Veil piercing unbound. Boston Univ Law Rev 93:89-137

Orts EW (2013) Business persons. Oxford University Press, Oxford

Petrin M (2013) Assumption of responsibility in corporate groups: Chandler v. Cape plc. Mod Law Rev 76:603-619 
Posner R (2007) Economic analysis of law, 7th edn. Wolters Kluwer Law \& Business, New York

Ramsay IM (1999) Allocating liability in corporate groups: an Australian perspective. Conn J Int Law 13:329-377

Rands WJ (1999) Domination of a subsidiary by a parent. Indiana Law Rev 32:421-456

Reich-Graefe R (2005) Changing paradigms: the liability of corporate groups in Germany. West Conn Law Rev 37:785-818

Skinner G (2015) Rethinking limited liability of parent corporations for foreign subsidiaries' violations of international human rights law. Wash Lee Law Rev 72:1769-1864

Strasser K (2005) Piercing the veil in corporate groups. Conn Law Rev 37:637-666

Talbot L (2013) Progressive corporate law for the 21st century. Routledge, Abingdon

Teubner G (2011) Networks as connected contracts. Hart Publishing, Oxford

Witting CA (2018) Liability of corporate groups and networks. Cambridge University Press, Cambridge 